\title{
Investigation of Anxiety and Peritraumatic Distress Levels in Context of Various Variables through Covid-19 Outbreak: Turkey, the UK and the USA Comparison
}

\author{
DOI: $10.26466 /$ opus. 830148
}

\begin{abstract}
Eda Ermagan Cağlar* - Nurcan Hamzaoğlu** -Yasemin Sanal Özcan*** Tugba Türk Kurtca****

* Lecturer, University of Northampton, Department of Psychology, Northampton, UK E-Posta: eda.e.caglar@northampton.ac.ukＯRCID: 0000-0002-9690-2898

** Ass. Professor, Istanbul Yeni Yuzyll University, Institute of Health Sciences, Istanbul/Turkey

E-Posta: nurcan.hamzaoglu@yeniyuzyil.edu.tr ORCID: 0000-0002-8471-0442

${ }^{* * *}$ Ass. Professor, Manisa Celal Bayar Uni. Faculty of Science and Letters, Manisa/Turkey

E-Posta: yasemin.sanal@cbu.edu.tr ORCID: 0000-0002-3147-6269

****Research Fellow, Trakya University, Department of Educational Sciences, Edirne/Turkey

E-Posta tugbaturk@trakya.edu.tr ORCID: $\quad$ 0000-0002-4361-3769
\end{abstract}

\begin{abstract}
The study aimed to gather socio-demographic information, compliance with personal/governmental precautionary measures from Turkish nationals (age 18 or older) reside in Turkey, the UK and the USA to investigate and compare the effects on peritraumatic distress and anxiety levels within these countries. Peritraumatic Stress and Anxiety Levels are measured by Peritraumatic Distress Inventory (PDI) and the StateTrait Anxiety Inventory (STAI). 70 participants from Turkey, 63 from the UK and 67 from the USA have participated in this causal-comparative study. According to the statistical analysis, even though there was no difference between three sample groups according to the STAI-State and PDI scores; the analysis showed that the STAI-Trait points of Turkey sample were higher than the other countries $(p<.01)$. This study identified variables such as being a woman, living alone, trusting official statements, and positive test results from relatives or acquaintances as factors that affect anxiety level. However, these factors differ when evaluated within the scope of country-based responses. This suggests that the level of anxiety is affected more by political decisions, preventive measures and social environment rather than by common cultural characteristics.
\end{abstract}

Anahtar Kelimeler: Covid-19, pandemic, anxiety, peritraumatic stress, psychological impact 


\section{Covid-19 Salgın Sürecinde Kaygı ve Peri-travmatik Stres Düzeyinin Çeşitli Değişkenler Bağlamında İncelenmesi: Türkiye, İngiltere ve Amerika Karşılaştırması}

$\ddot{O} z$

Bu çalışmada, Türkiye, İngiltere ve Amerika Birleşik Devletleri'nde (ABD) ikamet eden Türk vatandaşlarmın (18 yaş ve üstü) sosyo-demografik bilgi ve Covid-19 salgın sürecinde hükümet ve bireylerin kendileri tarafindan alınan önlemlere ilişkin algılarının alınması sonrasında; peri-travmatik stres ve kaygı düzeylerinin çeşitli değiş̧kenler açısından incelenmesi amaçlanmıştır. Çalışmada peri-travmatik stres ve kaygı düzeyleri Peri-travmatik Stres Envanteri ve Durumluk ve Sürekli Kaygı Ölçeği ile ölçülmüştür. Söz konusu ülkelerle yapılan bu nedensel karşılaştırmalı çalışmaya Türkiye'den 70, İngiltere'den 63 ve ABD'den 67 katılımo katılmıştır. Ístatistiksel analize göre Durumluk Kaygı Ölçeği ve Peritravmatik Stres Ölçeği puanlarında ülkeler arasında bir farklılık tespit edilmezken, Türkiye'deki katılımcılarm Sürekli Kaygı Ölçeği toplam puanlarmın diğer gruplara göre yüksek olduğu tespit edilmiştir ( $p<.01$ ). Bu çalışma kadın olmak, yalnız yaşamak, resmi kurumların açıklamalarına güven duymak, akraba veya tanıdıkların pozitif test sonuçları gibi değişkenleri kaygı düzeyini etkileyen faktörler olarak belirlemiştir. Ancak bu faktörler ülke bazında verilen yanıtlar kapsamında değerlendirildiğinde farklılıklar göstermektedir. Bu durum kaygı düzeyinin ortak kültürel özelliklerden ziyade siyasi kararlardan, önleyici tedbirlerden ve sosyal çevreden daha fazla etkilendiği düşündürmektedir.

Keywords: Covid-19, pandemi, anksiyete, peri-travmatik stres, psikolojik etki 


\section{Introduction}

In December 2019, an outbreak of a -later known to be- novel coronavirus (Covid-19) was reported in Wuhan, China. By the end of January 2020, the issue became international, reports on the infection started coming from different regions around the World. On the 30th January of 2020, the World Health Organization (2020a) considered and announced the virus as a Public Health Emergency of International Concern. In addition to other cases in the world; first cases were detected on the 21st of January in the USA, reported by the end of January in England and was officially announced by the Ministry of Health on the 11th March of 2020 in Turkey. Globally, as of April 24th, 2020, there have been 2,591,015 confirmed cases of Covid-19, including 178,686 deaths, reported to the World Health Organization (2020b).

As of the quick spread of the disease, many research were carried out on the epidemiological and clinical features of the virus (Chen et al., 2020; Dong et al., 2020, Rothan and Byrareddy, 2020). Following the clinical and epidemiological studies, the importance of emotional impact of the virus was realized. Studies focusing on immediate psychological reactions of the general population, infected and risk groups became one of the main concerns of the researchers. Literature review shows that, in studies, up to over $\% 50$ of the participants present high anxiety or worries to virus induced epidemics and pandemics (Goulia et al., 2010; Wang et al., 2020). According to an earlier study conducted with Chinese general population on Covid-19, more than half respondents presented moderate-to-severe psychological impact and one third showed moderate-to-severe anxiety (Wang et al., 2020). Duan and Zhu (2020) mention that any major epidemic outbreak will have negative effects on both individuals and society. After the SARS epidemic, psychological distress, such as anxiety and depressive symptoms, of survivors was significantly presented by Cheng, Wong, Tsang and Wong (2004). Lee and colleagues (2007) also presented that SARS survivors had elevated stress levels and worrying levels of psychological distress even a year after the outbreak. However, studies on factors related to this anxiety levels and distress are still lacking.

In some studies, it is mentioned that every patient is potentially at risk for acquiring and transmitting infectious diseases to other patients and ani- 
mals (Kumar et al., 2020). Since human-to-human transmission is a major risk for the novel virus, one of the most effective precautions was considered as 'social distancing' and 'isolation' against it. Based on this information some governments applied different levels of 'lock-downs' for public safety. A lock-down may refer to whether mandatory mass quarantines or non-mandatory recommendations to stay at home. Some governments preferred nation-wide lockdowns and some preferred time or age limitations. Regarding this, an estimation of 280 million people was under lockdown throughout Europe, 150 million in the US, nearly 1.3 billion in India and still 50-60 million in China according to an article published March 2020 (Lippi, Henry, Bovo and Sanchis-Gomar, 2020). In the same study, health risks such as physical inactivity, weight gain, behavioral addictions, insufficient sunlight exposure and social isolation were pointed out. Social isolation's possible outcomes are considered as depression, anxiety, misidentification of health deterioration. So even though this way of protection (lockdowns) seems particularly useful and strong against the virus transmission, it also seems to cause negative consequences on human psychology. The review article prepared by Brooks et al. (2020) reveals remarkable psychological results on lockdowns such as post-traumatic stress symptoms, confusion, and anger. They also mention related stressors; including longer quarantine duration, infection fears, boredom, financial loss, inadequate information in the review (Brooks et al., 2020).

To better deal with the psychological problems of the people involved with the virus, the variables related to those problems should be well understood and documented. Since the literature is lacking on the causes of psychological outcomes through the outbreak; the present study aimed to gather socio-demographic information, compliance with personal/governmental precautionary measures from Turkish people living in Turkey, the UK and the USA to investigate and compare the effects on peritraumatic distress and anxiety levels within these three countries. The present study is conducted to contribute on the literature about the causes of anxiety levels and distress through Covid-19 outbreak. 


\section{Method}

Causal-comparative research methodology was used to determine anxiety levels and factors affecting anxiety levels of Turkish nationals living in Turkey, the UK, and the USA during the Covid-19 pandemic.

Ethical approval was obtained from Turkish Ministry of Health (date:16/05/2020) and Ethics Board of Science, Social and Non-invasive Medical Research (date:21/05/2020, ref.:2020/04-05) to conduct the study. Upon receiving the formal approvals, as the social isolation measures were still in place, Demographic Information Form, Covid-19 Experience Information Form, Peritraumatic Distress Inventory (Brunet et al., 2001) and The StateTrait Anxiety Inventory (Spielberger et al., 1983) were prepared as online documents and an online survey was conducted in Turkish by Google Forms. Participants in the target group were firstly provided with an informed consent form and the survey was carried out by the participants who agreed to participate in the research.

\section{Population and Sample}

Target group of the study was the Turkish citizens living in the USA, the UK or Turkey. Thus, anxiety levels of participants with a common perception, were analyzed in the context of various variables within the scope of measures and methods of struggle taken, in three different countries.

Turkish nationals aged 18 or older who reside in Turkey, the UK and the USA and agree to participate was determined as study participation criteria. Decisions on design in accordance with the research aims would have an impact on the size of the sample. Borg and Gall (1979)'s study presents criteria to determine the sample size in relation to research method (cited in Cohen et al., 2000, p.93). Based on the related criteria, the present causalcomparative study with a survey design requires more than 50 samples. In accordance with this, 70 participants from Turkey, 63 participants from the UK and 67 participants from the USA have participated in this comparative study of aforementioned countries. 


\section{Data Collection Tools}

Demographic Information Form: A 10 question form was used to determine the demographic characteristics of the participants such as age, gender, marital status, professional and financial status, education, and their household.

Covid-19 Experience Information Form: An information form was used to identify participants' experiences with medical treatments regarding Covid19 , personal protection measures taken by the participants and their compliance with government protection measures. In order to evaluate these measures taken during the pandemic and determine to what extent to which it affects the individuals' stress and anxiety scores, the items such as "I comply with the warnings of the government officials; I pay attention to social distance rules; I have enough protective equipment for the pandemic (hand sanitizer, mask ...); I obey the rules of staying at home to be protected from the pandemic; I have been following general hygiene rules since the outbreak started; I have been following the rules of hand hygiene since the outbreak started; I use gloves in social areas since the outbreak started (at the markets, public transports..); I think the government observes public health from the practices it carried out; Government's determination of emergency numbers, health equipment procurement, investment in healthcare staff by taking precautions such as measures to meet the health needs of the society" were asked to participants. This information form was created by the researchers in the form of a 3-point Likert Scale and yes/no questions to determine if they or someone they know was tested/diagnosed or deceased with Covid-19.

Peritraumatic Distress Inventory (PDI): The instruction for the Peritraumatic Distress Inventory was developed by Brunet et al. (2001) to assess peritraumatic distress. Peritraumatic stress refers to the feeling of fear, helplessness and dread experienced during or shortly after a traumatic event (Brunet et al., 2001). Studies indicate that peritraumatic stress level is a predictor of post-traumatic stress disorder in the long term (Başoğlu et al., 2002; Kannis-Dymand et al., 2019; Nishi et al., 2010; Rosendal et al., 2011; Rybojad et al., 2019). PDI is to rate the extent to which each item is experienced during the traumatic event and immediately after. The response format is a 
Likert scale that ranges from 0 to 4 ( $0=$ not at all, $1=$ slightly, $2=$ somewhat, $3=$ very, and $4=$ extremely true). The total score is obtained by determining the mean response across all 13 items. Higher scores on the scale indicate higher distress levels. Cronbach's alpha internal consistency coefficient was determined as .88 for the entire scale, while negative emotions subdimension internal consistency coefficient was .84, perceived life threats and physical arousal subscale internal consistency coefficient was .80 (ErmaganCaglar et al., in-press). As a result of the exploratory factor analysis, the original version of the scale which has a two-factor structure, was found to be $61.62 \%$ of the variance explained by a three-factor structure, and as a result of the modification conformity factor analysis, AIC value $=214,389$ and ECVI value $=.961$ were determined.

The State-Trait Anxiety Inventory (STAI): The original scale was developed by Spielberger (1970) and the Turkish version was published by Öner and Le Compte (1983). High scores reflect high anxiety levels and low scores reflect low anxiety levels. The internal-consistency alpha coefficients of the State Anxiety Inventory ranged from 0.90 to 0.96 . The internal-consistency alpha coefficients of the Trait Anxiety Inventory ranged from 0.81 to 0.90 (Öztürk, 2008). The responses in the STAI-State are formulated as four-point Likert scale with the following category options: (1) Not at all, (2) Somewhat, (3) Moderately so and (4) Very much so and the responses in the STAI-Trait have the following category options: (1) Almost never, (2) Sometimes, (3) Often and (4) Almost Always. There are 20 questions on both scales, resulting in a total of 40 questions. The scores obtained from both scales theoretically range from 20 to 80 .

\section{Data Analysis}

In the present study, causal-comparative research methodology, ANOVA and independent sample t-test analysis were carried out for parametric differences; Kruskal Wallis and Mann Whitney $U$ analyses were performed for the analysis of non-parametric differences. In addition, Pearson correlation analysis was used for correlation analysis. SPSS 25 program was used to analyze the collected data. 


\section{Results}

\section{Participants}

200 participants were enrolled in the research. 35\% (n:70) of them were from Turkey, 31.5\% (n:63) were from the UK and 33.5\% (n:67) were from the USA. Of the total participants $73 \%$ (n:146) were women and 27\% (n:54) were men. When the gender of the participants was analyzed by countries, 79.4\% (n:50) of the participants in the UK sample; $67.2 \%$ (n:45) in the USA sample; $72.9 \%$ in the Turkey sample (n:51) were women. Average age of the participants in the study was $\overline{X=33.70, S d=10.12 . ~}$

95 (47.5\%) respondents displayed "married/have a partner"; 72 (36\%) respondents displayed "single", 28 (14\%) respondents "preferred not to answer" and $5(2.5 \%)$ were determined as missing data.

Participants were also asked about with whom they live together. According to the answers 17 (8,5\%) participants live alone, whereas 183 (91,5\%) live together with someone. Participatns who live someone were asked to give detail. The answers show that $100(50 \%)$ live with family or partner, 70 $(35 \%)$ live with their parents, $13(6.5 \%)$ share the place with friends.

\section{Total Scores of Participants}

Participants' total scale point averages for Peritraumatic Distress Inventory (PDI) is $X=15.91(\mathrm{Sd}=8.16)$, for STAI-State is $\bar{X}=43.82(\mathrm{Sd}=11.00)$ and for STAI-Trait is $X=43.02(S d=10.53)$. As a result of evaluation according to the countries; the UK participants' mean score of PDI is $\bar{X}=16.06(\mathrm{Sd}=8.13)$, the mean score of the STAI-State is $X=43.97(\mathrm{Sd}=11.63)$ and the mean score of STAI-Trait is $X=41.65$ ( $\mathrm{Sd}=8.98)$. And for the USA sample, PDI mean score is $\bar{X}=16.06(\mathrm{Sd}=8.13)$, STAI-State mean score is $\bar{X}=43.97(\mathrm{Sd}=11.66)$ and STAI-Trait mean score is $X=41.65(\mathrm{Sd}=8.98)$. In Turkey sample, PDI mean scores is $X=16.81(\mathrm{Sd}=8.90)$, STAI-State mean score is $X=44.96(\mathrm{Sd}=10.21)$ and STAI-Trait mean score is $\bar{X}=45.78(\mathrm{Sd}=11.33)$. The average score levels determined during the applications varies between 36 and 41 . 


\section{Scale Point Differences Among the Countries}

Table 1. ANOVA Results to Determine Whether Scale Points Differentiate According to Country Variable

\begin{tabular}{|c|c|c|c|c|c|c|c|}
\hline & & ANOVA Results & & & & & \\
\hline & Group & Source of Variance & SS & sd & MS & F & $\mathrm{p}$ \\
\hline \multirow[t]{4}{*}{ PDI } & Turkey & Between Groups & 138.19 & 2 & 69.09 & \multirow[t]{4}{*}{1.039} & \multirow[t]{4}{*}{.356} \\
\hline & the UK & Within Groups & 13104.18 & 197 & 66.51 & & \\
\hline & the USA & Total & 13242.38 & 199 & & & \\
\hline & Total & & & & & & \\
\hline \multirow{4}{*}{$\begin{array}{l}\text { STAI- } \\
\text { State }\end{array}$} & Turkey & Between Groups & 207.32 & 2 & 103.66 & \multirow[t]{4}{*}{.855} & \multirow[t]{4}{*}{.427} \\
\hline & the UK & Within Groups & 23895.55 & 197 & 121.29 & & \\
\hline & the USA & Total & 24102.87 & 199 & & & \\
\hline & Total & & & & & & \\
\hline \multirow{4}{*}{$\begin{array}{l}\text { STAI- } \\
\text { Trait }\end{array}$} & Turkey & Between Groups & 822.32 & 2 & 411.16 & \multirow[t]{4}{*}{3.808} & \multirow[t]{4}{*}{$.024^{*}$} \\
\hline & the UK & Within Groups & 21270.55 & 197 & 107.97 & & \\
\hline & the USA & Total & 22092.87 & 199 & & & \\
\hline & Total & & & & & & \\
\hline
\end{tabular}

${ }^{*} \mathrm{p}<.05$

In accordance with the Post-Hoc LSD Test Results after One-Way ANOVA made in order to determine which subgroups of STAI-Trait points differentiate according to country variable, a significant statistical difference was found at a level of $(p<.05)$ in favor of Turkey group between Turkey and the USA and the UK groups. Accordingly, the STAI-Trait points of Turkey group are higher than the other counties groups (Table 2).

Table 2. Post-Hoc LSD Test Results after One-Way ANOVA to Determine Which Subgroups of STAI-Trait Points Differentiate According to Country Variable

\begin{tabular}{lllll}
\hline Groups (i) & Groups $(\mathrm{j})$ & $\mathrm{MD}(\mathrm{I}-\mathrm{j})$ & $\mathrm{SE}$ & $\mathrm{p}$ \\
\hline \multirow{2}{*}{ Turkey } & the UK & $4,13492^{*}$ & 1,80452 &, 023 \\
\cline { 2 - 5 } & the USA & $4,35288^{*}$ & 1,77595 &, 015 \\
\hline \multirow{2}{*}{ the UK } & Turkey & $-4,13492^{*}$ & 1,80452 &, 023 \\
\cline { 2 - 5 } & the USA &, 21796 & 1,82356 &, 905 \\
\hline \multirow{2}{*}{ the USA } & Turkey & $-4,35288^{*}$ & 1,77595 &, 015 \\
\cline { 2 - 5 } & the UK &,- 21796 & 1,82356 &, 905 \\
\hline
\end{tabular}

${ }^{*} \mathrm{p}<.05$

\section{Relations Between Scales}

As stated in Table-3, a positive significant statistical difference at a level of $\mathrm{p}<.01$ has been detected between the PDI and STAI-State $(r=.731 ; \mathrm{p}<.01)$, and STAI-Trait $(\mathrm{r}=.598 ; \mathrm{p}<.01)$, and between the State-Trait Anxiety Inventory ( $\mathrm{r}=$ $.608, \mathrm{p}<.01)$. 
Table 3. Relations between Peritraumatic Distress Inventory, STAI-State and STAI-Trait Points

\begin{tabular}{|c|c|c|c|c|c|c|c|c|}
\hline & \multicolumn{2}{|c|}{ Total Sampling } & \multicolumn{2}{|c|}{ the UK } & \multicolumn{2}{|c|}{ the USA } & \multicolumn{2}{|c|}{ Turkey } \\
\hline & PDI & STAI State & PDI & STAIState & PDI & STAI-State & PDI & STAI- State \\
\hline STAI-State & $.731^{*}$ & & ,710* & & $.810^{*}$ & & $.692^{*}$ & \\
\hline STAI-Trait & $.598^{*}$ & $.608^{*}$ & $660^{*}$ & ,687* & $.691^{*}$ & $.660^{*}$ & $.493^{*}$ & $.508^{*}$ \\
\hline
\end{tabular}

${ }^{*} \mathrm{p}<.001$

\section{Differences According to Demographic Variables}

Gender : As a result of independent-samples t-test, made in order to determine whether the PDI, STAI-State and STAI-Trait points of total participants differ in accordance with the gender variable of the participants, the difference between the arithmetic means of the groups was found statistically significant. It was determined that the women's scores are higher than the male participants in PDI $(t=5,122 ; p<.01)$, STAI-State $(t=3.504 ; p<.01)$ and in STAI-Trait $(\mathrm{t}=3,734 ; \mathrm{p}<.01)$. As a result of evaluation by using nonparametric Mann Whitney-U test performed in order to determine whether the scale points according to the countries significantly differ in terms of gender variable, it was found that; while there was no statistically significant difference between the groups for PDI, STAI-State, and STAI-Trait total points for the UK sample at the level of $\mathrm{p}<.05$; on the other hand, the scores of women in the USA and Turkey sample was higher than that of men. For the USA, PDI is $(U=320.000, Z=2.340)$, STAI-State is $(U=297.000, Z=-2.646)$, and the STAI-Trait is $(\mathrm{U}=330.00, Z=-2.205)$; and for Turkey, PDI is $(\mathrm{U}=176.500, \mathrm{Z}=-4.075)$, STAI-State is $(\mathrm{U}=316.500, \mathrm{Z}=2.646)$, and the STAITrait is $(\mathrm{U}=293.500, \mathrm{Z}=-2.526)$.

Marital Status: As a result of ANOVA made in order to determine whether there is a significant difference between the total participants scale points according their marital status, it was found that the difference between the arithmetic means of STAI-State $(\mathrm{F}=5.289 ; \mathrm{p}<.05)$ and STAI-Trait $(\mathrm{F}=6.730$; $\mathrm{p}<.01)$ of the relevant groups are statistically significant. In accordance with the Post-Hoc Analysis conducted in order to determine which group the difference is originated from, the scale scores of the STAI-State and STAITrait of the participants who has no partner and live alone are found statistically significantly higher than the married ones $(\mathrm{p}<.05)$. 
In accordance with the Kruskal Wallis analysis performed in order to determine whether there is a significant difference between groups according to countries; it was found that while the arithmetic means of the scale scores of the participants in the UK sample did not show statistically significant difference according to the marital status variable. However, a statistically significant differences between the groups in terms of STAI-State $\left(x^{2}=6,191\right.$; $\mathrm{df}=2 ; \mathrm{p}<.05)$ in the USA Sample, and STAI-Trait $\left(\mathrm{x}^{2}=6.526, \mathrm{df}=2, \mathrm{p}<.05\right)$ in Turkey sample is observed.

As a result of Mann Whitney-U analysis conducted in order to indicate at which group the difference differs, it was found that, in the USA Sample, the STAI-State scores of participants with no partner statistically significantly higher $(\mathrm{U}=4.500 ; \mathrm{Z}=-2.083, \mathrm{p}<.05)$ than those who has partners. Moreover, the STAI-State scores of the participants who has partners were also statistically significantly higher $(U=13.000 ; Z=-2.366, p<.05)$ than the other married participants. Besides, in Turkey sample, the STAI-Trait scores of single participants with no partner is found statistically significantly higher $(\mathrm{U}=274.500 ; \mathrm{Z}=-2.498, \mathrm{p}<.05)$ than those who has partners.

\section{Analysis on "With Whom They Live" Variable}

In accordance with the Kruskal Wallis analysis performed in order to determine whether there were differences of scores based on "with whom the participants live together" (alone, with family or partner, parents or friends were the given answers by the participants) variables, a statistically significant difference could not be detected both in terms of total scale scores of participants and also among the groups in the UK, the USA and Turkey for PDI, STAI-State and STAI-Trait ( $\mathrm{p}>$.05).

\section{Differences According to the Measures}

\section{Trust in Government Statements}

According to the One-Way Analysis of Variance (ANOVA) results conducted in order to detect whether the scale points differ according to the "trust in government statements" variable; there was no statistically significant difference between the answers "Agree", "Not sure" and "Disagree" for PDI, STAI-State and STAI-Trait according to both total and country samples (p> .05) (Table 4). 
Table 4. ANOVA Results to Determine Whether Scale Points Differentiate According to the "Trust in Government Statements" Variable

\begin{tabular}{|c|c|c|c|c|c|c|c|c|c|c|c|}
\hline & \multicolumn{5}{|c|}{ Values $(\mathrm{f}, \mathrm{X}, \mathrm{Sd})$} & \multicolumn{6}{|c|}{ ANOVA Results } \\
\hline & & Group & $\mathrm{f}$ & $X$ & $\mathrm{Sd}$ & $\begin{array}{l}\text { Source } \\
\text { of } \\
\text { Variance }\end{array}$ & SS & $\mathrm{df}$ & MS & $\mathrm{F}$ & $\mathrm{p}$ \\
\hline \multirow{12}{*}{ 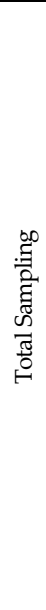 } & \multirow{4}{*}{ PDI } & Disagree & 65 & 15.03 & 8.58 & $\begin{array}{l}\text { Between } \\
\text { Groups }\end{array}$ & 256.28 & 2 & 128.14 & \multirow{4}{*}{1.944} & \multirow{4}{*}{.146} \\
\hline & & Not sure & 48 & 17.89 & 7.55 & $\begin{array}{l}\text { Within } \\
\text { Groups }\end{array}$ & 12986.09 & 197 & 65.91 & & \\
\hline & & Agree & 87 & 15.47 & 8.06 & Total & 13242.38 & 199 & & & \\
\hline & & Total & 200 & 15.91 & 8.15 & & & & & & \\
\hline & \multirow{4}{*}{$\begin{array}{l}\text { STAI- } \\
\text { State }\end{array}$} & Disagree & 65 & 44.43 & 10.61 & $\begin{array}{l}\text { Between } \\
\text { Groups }\end{array}$ & 35.55 & 2 & 17.77 & \multirow{4}{*}{.146} & \multirow{4}{*}{.865} \\
\hline & & Not sure & 48 & 43.47 & 10.78 & $\begin{array}{l}\text { Within } \\
\text { Groups }\end{array}$ & 24067.32 & 197 & 122.16 & & \\
\hline & & Agree & 87 & 43.56 & 11.51 & Total & 24102.87 & 199 & & & \\
\hline & & Total & 200 & 43.82 & 11.00 & & & & & & \\
\hline & \multirow{4}{*}{$\begin{array}{l}\text { STAI- } \\
\text { Trait }\end{array}$} & Disagree & 65 & 41.35 & 9.20 & $\begin{array}{l}\text { Between } \\
\text { Groups }\end{array}$ & 274.24 & 2 & 137.12 & \multirow{4}{*}{1.238} & \multirow{4}{*}{.292} \\
\hline & & Not sure & 48 & 43.56 & 9.38 & $\begin{array}{l}\text { Within } \\
\text { Groups }\end{array}$ & 21818.62 & 197 & 110.75 & & \\
\hline & & Agree & 87 & 43.97 & 11.93 & Total & 22092.87 & 199 & & & \\
\hline & & Total & 200 & 43.02 & 10.53 & & & & & & \\
\hline
\end{tabular}

\section{Analysis on Governmental Precautionary Measures}

According to the results of One-Way ANOVA conducted in order to determine whether the scale points differ according to the variable "I think the government observes public health"; there was no statistically significant difference between the answers "Agree", "Not sure" and "Disagree" for PDI, STAI-State and STAI-Trait ( $\mathrm{p}>$.05). Besides, in the assessment made in terms of country samples, while there is no statistically significant difference of the scale points among the groups in the USA and Turkey samples, however, it was found in the UK sample that the STAI-State scores of the participants who answered "Disagree" was statistically significantly higher than participants who answered "Not sure" and "Agree" $\left(\mathrm{X}^{2}=8.515 \mathrm{df}=2 \mathrm{p}=.014\right)$ (Table 5). 
Table 5. ANOVA Results to Determine Whether the Scale Points Differentiate According to the "I think the Government observes Public Health from the Practices it carries out" Variable

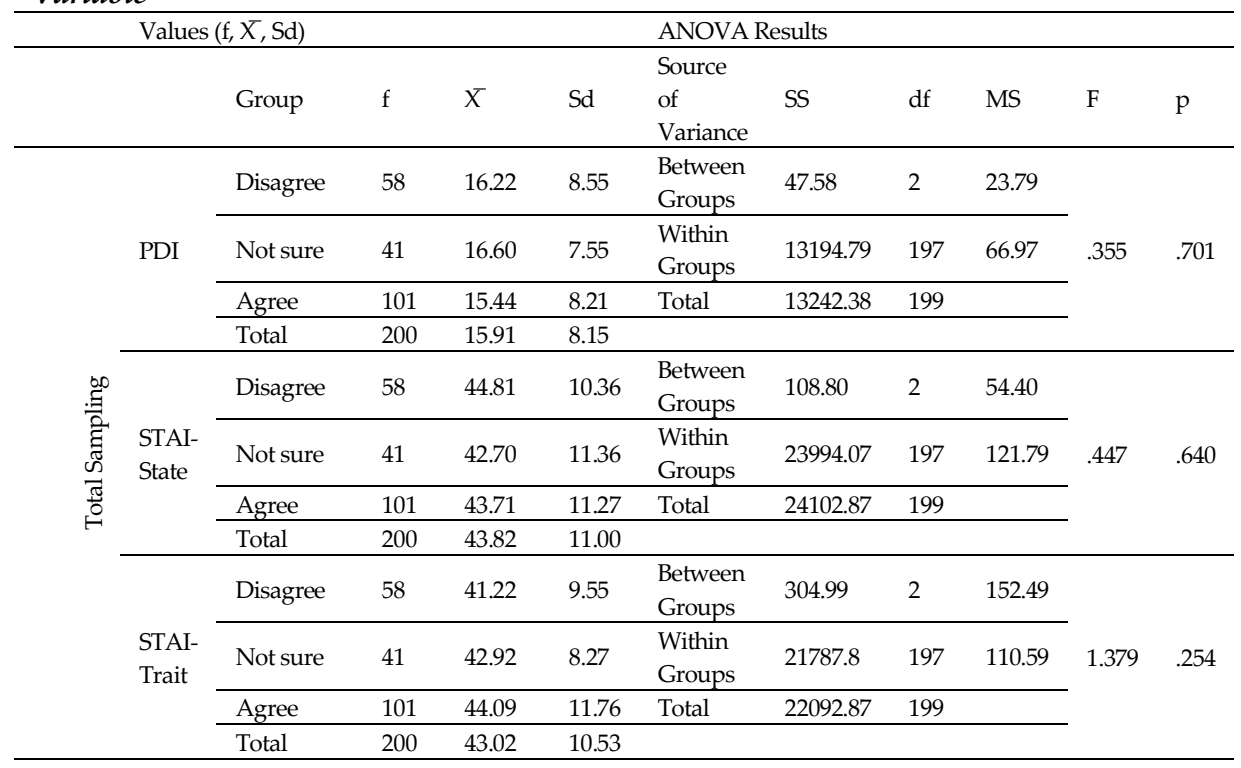

In accordance with the results of One-Way ANOVA conducted in order to determine whether the scale scores differ according to the variable of "meeting the health needs"; there was no statistically significant difference between the answers "I agree", "Not sure" and "Disagree" for PDI, STAIState and STAI-Trait ( $\mathrm{p}>$.05). Furthermore, in the assessment made based on countries, there is no statistically significant difference detected in terms of the scale points among the groups in the USA and Turkey samples. However, it was found in the UK sample that while there is no significant difference between the answers "I agree", "Not sure" and "Disagree" for STAIState and STAI-Trait scale points, PDI scale points of the participants who answered "Not sure" was significantly higher than participants who answered "Agree" ( $\mathrm{U}=70.000, \mathrm{Z}=-2.179)$ (Table 6). 
Table 6. ANOVA Results to Determine Whether Scale Points Differentiate According to the "Government's determination of emergency numbers, health equipment procurement, investment in healthcare staff by taking precautions such as measures to meet the health needs of the society" Variable.

\begin{tabular}{|c|c|c|c|c|c|c|c|c|c|c|c|}
\hline & \multicolumn{5}{|c|}{ Values $(f, X, S d)$} & \multicolumn{6}{|l|}{ ANOVA Results } \\
\hline & & Group & $\mathrm{f}$ & $x$ & $\mathrm{Sd}$ & $\begin{array}{l}\text { Source of Vari- } \\
\text { ance }\end{array}$ & SS & df & MS & $\mathrm{F}$ & $\mathrm{p}$ \\
\hline & \multirow{4}{*}{ PDI } & Disagree & 60 & 15.46 & 8.10 & Between Groups & 170.45 & 2 & 85.22 & \multirow{4}{*}{1.284} & \multirow{4}{*}{.27} \\
\hline & & Not sure & 35 & 17.91 & 9.39 & Within Groups & 13071.92 & 197 & 66.35 & & \\
\hline & & Agree & 105 & 15.49 & 7.71 & Total & 13242.38 & 199 & & & \\
\hline & & Total & 200 & 15.91 & 8.15 & & & & & & \\
\hline & \multirow{4}{*}{$\begin{array}{l}\text { STAI- } \\
\text { State }\end{array}$} & Disagree & 60 & 44.53 & 9.74 & Between Groups & 145.027 & 2 & 72.51 & \multirow{4}{*}{.596} & \multirow{4}{*}{.552} \\
\hline & & Not sure & 35 & 45.00 & 11.39 & Within Groups & 23957.84 & 197 & 121.61 & & \\
\hline & & Agree & 105 & 43.02 & 11.57 & Total & 24102.87 & 199 & & & \\
\hline \multirow{5}{*}{ 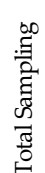 } & & Total & 200 & 43.82 & 11.00 & & & & & & \\
\hline & \multirow{4}{*}{$\begin{array}{l}\text { STAI- } \\
\text { Trait }\end{array}$} & Disagree & 60 & 40.81 & 8.23 & Between Groups & 423.49 & 2 & 211.74 & \multirow{4}{*}{1.925} & \multirow{4}{*}{.149} \\
\hline & & Not sure & 35 & 44.31 & 10.57 & Within Groups & 21669.38 & 197 & 109.99 & & \\
\hline & & Agree & 105 & 43.85 & 11.54 & Total & 22092.87 & 199 & & & \\
\hline & & Total & 200 & 43.02 & 10.53 & & & & & & \\
\hline
\end{tabular}

In order to evaluate both the government and the personal measures taken during the pandemic and determine to what extent to which it affects the individuals' stress and anxiety scores, the items such as "I comply with the warnings of the government officials; I pay attention to social distance rules; I have enough protective equipment for the pandemic (hand sanitizer, mask ...); I obey the rules of staying at home to be protected from the pandemic; I have been following general hygiene rules since the outbreak started; I have been following the rules of hand hygiene since the outbreak started; I use gloves in social areas since the outbreak started (at the markets, public transports..)" were asked to participants. As a result of analysis for these questions, it was not detected any statistically significant differences both in terms of total scale scores of participants and also among the groups of country samples according to "Agree", "Not sure", "Disagree" answers ( $\mathrm{p}>05)$.

\section{Differences According to “Covid-19 Testing" Variable}

As a result of the Mann Whitney-U test conducted in order to determine whether the participants' PDI, STAI-State and STAI-Trait scores significantly differ according to the "Covid-19 testing" variable; a statistically significant difference could not be detected both in terms of total scale scores of partici- 
pants and also among the groups of the UK, the USA and Turkey samples obtained scores within terms of whether an acquaintance, a family member or oneself has ever taken Covid-19 test. According to the non-parametric Mann-Whitney $U$ test result that was conducted in order to determine whether the scale points of the participants differ in the UK, the USA and Turkey samples; a statistically significant difference could not be detected among the groups in UK and Turkey samples according to the variables of whether the result of Covid-19 test of an acquaintance, a family member or oneself is positive or not. However, in the USA sample, STAI-State scores were found higher in terms of all three variables compared to the other participants. Moreover, a statistically significant difference could not be detected among the groups of country samples for PDI, STAI-State and STAI-Trait scores in terms of "One of my family members died due to Covid-19" and "One of my acquaintance died due to Covid-19" variables.

\section{Discussion}

Generally, the pandemics like Covid-19 cause psychological negativities such as anxiety and fear in the majority of the society, because they affect many people (Krueger, 2018; Perin, 2015; Rana, 2020). This increase in anxiety does not only affect the psychological health of individuals but also causes an increase in the observation of somatic diseases; and also, besides the individual, this change affects individuals' intimate circles such as spouse, child and family and causes rise in anxiety (K1lınç et al., 2017). Therefore, it is seen that the individuals' anxiety levels and the factors affecting them are important in terms of the strategies to be developed to prevent this problem that also threatens the public health.

The spreading process and results of epidemic diseases vary among the societies due to factors such as human biology, social environment, and lifestyles (Herring, 2007). The present study found out that participants are concerned in a moderate degree in all three countries, and STAI-Trait points of the participants in Turkey sample was found higher than the UK and the USA samples (Table 2). Although the measures (such as lockdowns) taken during the epidemic process are effective in preventing the spread of the disease, they are the factors that affect the anxiety level (Çırakoğlu, 2011; Teo, 2005). This high level of STAI-Trait scores in Turkey sample while compared with the other country samples shall be derived from the preven- 
tive measures taken in this process that was considered to lead to a negativity in economy in the long term. Hence, in accordance with the study conducted by Bostan et al. (2020) it is stated that the participants were worried about the appropriateness of the economic measures taken. In addition to the personal characteristics specified by Bronfenbrenner (1977; 1979), this result is in line with the ecological system approach regarding the effects of many distant interaction factors such as family, neighbor, its interactions, and policies carried out. At this point, although it is easier to reach the health services in Turkey, it is thought that the economic uncertainty and unemployment concerns lead the participants living in this country to have higher anxiety during the Covid-19 outbreak while compared with the other countries' participants.

One of the factors affecting the anxiety level is seen as reliance on official sources regarding outbreak. Especially when encountered an uncertainty, the trust level of individuals to the information from official sources affects how they perceive the risk (Siegrist et al., 2001; 2005). According to the report prepared by the American Psychological Association (2020), 7 out of 10 individuals $(67 \%)$ in the USA express that the reactions of the government cause stress on them. Trust also plays an important role in people's riskpreventing behaviors (McComas, 2001). In this case, it might be said that the greater trust on government statements the people feel has an affect on the smaller perceived risk they have. It is in accordance with the study conducted by Liu et al. (2020), which stated that having information about Covid-19 is a protective factor against anxiety. In the present study, while the participants' anxiety and concern levels during the pandemic process in the USA and Turkey samples has no statistical significance in terms of relying upon the measures taken by the government, the stress levels of participants who distrust the government in the UK sample is found higher (Table 4). The relevant findings show that trust in government statements is effective in developing protective behavior habits and reducing anxiety level during epidemic process. It is thought that the reliance upon the government's statements will also reduce situations that would adversely affect the epidemic process, such as panic buying behavior, non-compliance with the measures that may occur as a result of protective measures such as isolation, travel restriction and lockdowns to prevent the spread of the disease. As a matter of fact, the relevant studies show that both concern and anxiety are 
generally associated with responsible and protective health behavior; it shows that the factors such as compliance with the precautions taken, applying health protective behaviors and having information about the stressful event affect the anxiety and concern levels (Herring, 2007; Sweeny and Dooley, 2017; Wang et al. 2020).

Gender was also considered as an important variable in the present study. In some studies that are conducted in different epidemic periods with high lethal effects such as Covid-19; anxiety levels in accordance to gender variable was inspected and it is reported that women are at risk-group in terms of high anxiety levels (Çırakoglu, 2011; Leung et al., 2005; Raude and Setbon, 2009). In a study, conducted in China, more than a quarter of the participants reported moderate and severe anxiety, and being a woman was associated with anxiety (Wang et al., 2020). Shevlin et al. (2020) stated that the anxiety levels of women are higher than that of men in their studies performed with 2025 participants. In the present study, it was found that although there is no significant difference at the anxiety levels of participants in the UK sample according to the gender variable, but parallel to Shevlin's aforementioned study it was detected that the anxiety levels of women are higher than of men in both the USA and Turkey samples. In this context, it is thought that, the relevant results are found to be compatible with the findings of the literature indicating that women have a high perception of health risk (Greenberg and Schnieder, 1995; Gustafson, 1998; Shevlin et al., 2020; Wang et al., 2020).

In terms of marital status variable, it was observed that the anxiety levels of the individuals living alone were higher than the individuals that are married or have partners. These results suggest that social support affects the perceived level of anxiety. Thus, the studies have shown that perceived social support has a decreasing effect on psychological symptoms such as stress, depression and anxiety (Benight, Swift, Sanger, Smith, and Zeppelin, 1999; Bonanno, 2008; Lev and Owen, 1996; Mak, 2009). In this process, considering the social isolation and the social support comes into prominence in terms of psychosocial adjustment both during and after the pandemic. Pandemic and related restriction measures, and the relevant measures such as quarantine, social distancing and self-isolation have a detrimental effect on emotional health. In particular, increased loneliness and reduced social interaction are commonly known as risk factors for various mental disorders 
such as schizophrenia and major depression. It is thought that the anxiety regarding one's own health and loved ones' health (especially the elderly or individuals with any chronic illness) and future uncertainty can create fear, depression, and anxiety, or exacerbate these symptoms. The prolongation of the relevant concerns increases the risk of serious and disabling psychological health problems among adult men and women, including panic, obsessive-compulsive, stress, and trauma related disorders (Fiorillo and Gorwood, 2020).

The recent studies show that an acquaintance or a relative's Covid-19 positive diagnosis is an anxiety-increasing factor (Cao et al., 2020; Moghanibashi et al., 2020). On the contrary, in the present study, the fact of an acquaintance or a relative's Covid-19 positive diagnosis does not lead to a significant difference at the anxiety levels within terms of Turkey and the UK samples. However, in the USA sample, it was seen that the positive test results of both one-self and a relative or an acquaintance increased the level of anxiety. It is assumed that the relevant difference in the findings may be due to the difference in individuals' access to health services in the countries where they live.

Consequently, in accordance with the findings of the study, being a woman, living alone, trust in official institutions, positive test results of a relative or an acquaintance determined as factors that affect the level of anxiety. However, while evaluated on the basis of Turkey, the UK and the USA samples, it was found that these factors pointed to different reasons; it was observed that political decisions, preventive measures, social environment and economic conditions affect the individuals' anxiety level rather than common cultural characteristics.

\section{Suggestions}

Considering the data obtained in the present study, it is seen that sharing information and policies made by the administrations regarding the epidemic process with individuals, have an important effect both in respect to social isolation practices and in reducing the anxiety experienced by individuals. While evaluated by the World Health Organization's (2020b) statement that the increase in anxiety and concern level is a condition that weakens the immune system and increases the incidence of diseases, it is clear that the epidemic process requires a transparent and precautionary ap- 
proach to prevention and response, involving experts from different disciplines.

Additionally, as determined in the present research, the individuals started to experience stress and anxiety problems because of the changes in various fields, primarily economy, health and social contact, brought about by the Covid-19 process. As stated in the literature, the increase in stress and anxiety level may cause other psychological problems to arise. At this point, it is important to include social and psychological support services both within the scope of the measures taken during the epidemic process and by the beginning of the normalization process. Particularly, considering the problem areas that may be encountered in the long term, it is seen that it is required to identify risk groups within the scope of preparatory works for similar processes and to ensure that these groups benefit from social and psychological support. Compliance with ethical standards.

\section{Conflict of interest}

The authors declare that they have no conflict of interest.

\section{Ethical approval}

All procedures performed in studies involving human participants were in accordance with the ethical standards of the institutional and/or national research committee and with the 1964 Helsinki declaration and its later amendments or comparable ethical standards.

\section{Informed consent}

Informed consent was obtained from all individual participants included in the study.

\section{References}

Ann-Herring, D., and Sattenspiel, L. (2007). Social contexts, syndemics, and infectious disease in northern Aboriginal populations. American Journal of Human Biolo8y: The Official Journal of the Human Biology Association, 19(2), 190-202.

American Psychological Association (2020). Stress in the Time of COVID-19. https://www.apa.org/news/preSd/releases/streSd/2020/streSd-in-americacovid.pdf Last retrieved date: 28.05.2020. 
Asmundson G.J. and Taylor, S. (2020). How health anxiety influences responses to viral outbreaks like COVID-19: What all decision-makers, health authorities, and health care professionals need to know. J Anxiety Disord. 71, 102211.

Başoğlu, M., Şalcioğlu, E., and Livanou, M. (2002). Traumatic stresd responses in earthquake survivors in Turkey. Journal of Traumatic StreSd: Official Publication of The International Society for Traumatic Stress Studies, 15(4), 269-276.

Benight, C. C., Swift, E., Sanger, J., Smith, A., and Zeppelin, D. (1999). Coping selfefficacy as a mediator of distress following a natural disaster. Journal of Applied Social Psychology, 29(12), 2443-2464.

Bonanno, G. A., Ho, S. M., Chan, J. C., Kwong, R. S., Cheung, C. K., Wong, C. P., and Wong, V. C. (2008). Psychological resilience and dysfunction among hospitalized survivors of the SARS epidemic in Hong Kong: a latent class approach. Health Psychology, 27(5), 659.

Brooks, S. K., Webster, R. K., Smith, L. E., Woodland, L., Wessely, S., Greenberg, N., \& Rubin, G. J. (2020). The psychological impact of quarantine and how to reduce it: Rapid review of the evidence. The Lancet., 395(1022), 912-920.

Bronfenbrenner, U. (1977). Toward an experimental ecology of human development. American Psychologist, 32, 513-531.

Bronfenbrenner, U. (1979). The ecology of human development: Experiments by nature and design. Cambridge, MA: Harvard University Press.

Brunet A, Weiss DS, Metzler TJ, Best SR, Neylan TC, Rogers C, et al. (2001). The Peritraumatic Distress Inventory: A proposed measure of PTSD criterion A2. Am J Psychiatry, 158: 1480-1485.

Burke, B. L., Kosloff, S., and Landau, M. J. (2013). Death goes to the polls: A metaanalysis of mortality salience effects on political attitudes. Political Psychology, 34(2), 183-200. https://doi.org/10.1111/pops.12005

Cao, W., Fang, Z., Hou, G., Han, M., Xu, X., Dong, J., and Zheng, J. (2020). The psychological impact of the COVID-19 epidemic on college students in China. Psychiatry Research, 112934.

Chen, N., Zhou, M., Dong, X., Qu, J., Gong, F., Han, Y., Qiu, Y., Wang, J., Liu, Y., Wei, Y., Xia, J, Yu, T., Zhang, X. and Zhang, L. (2020). Epidemiological and clinical characteristics of 99 cases of 2019 novel coronavirus pneumonia in Wuhan, China: A descriptive study. The Lancet, 395(10223), 507-513

Cheng, S.K., Wong, C.W., Tsang, J., and Wong, K.C. (2004). Psychological distress and negative appraisals in survivors of severe acute respiratory syndrome (SARS). Psychological Medicine, 34(7), 1187-1195. 
Çırakoğlu, O. C. (2011). Domuz gribi (H1N1) salgınıla ilişkili algıların, kaygı ve kaçnma düzeyi değiş̧enleri bağlamında incelenmesi. Turk Psikoloji Dergisi, 26(67).

Dong, Y., Mo, X. and Hu, Y. (2020). Epidemiological characteristics of 2143 pediatric patients with 2019 coronavirus disease in China. Pediatrics. doi: 10.1542/peds.2020-0702

Duan, L., and Zhu, G. (2020). Psychological interventions for people affected by the COVID-19 epidemic. The Lancet Psychiatry, 7(4), 300-302.

Erceg, N., Ružojčć, M., and Galic, Z. (2020, April 10). Misbehaving in the corona crisis: The role of anxiety and unfounded beliefs. https://doi.org/10.31234/osf.io/cgiw8

Ermağan Çağlar,E., Türk Kurtça, T., Hamzaoğlu, N. and Sanal Özcan, Y. (in-press). Peritravmatik Stres Envanteri (PDI) Türkçe Geçerlik ve Güvenirlik Çalışması.

Fiorillo, A., and Gorwood, P. (2020). The consequences of the COVID-19 pandemic on mental health and implications for clinical practice. European Psychiatry, 1-4.

Goulia, P., Mantas, C., Dimitroula, D., Mantis, D., \& Hyphantis, T. (2010). General hospital staff worries, perceived sufficiency of information and associated psychological distress during the $\mathrm{A} / \mathrm{H} 1 \mathrm{~N} 1$ influenza pandemic. BMC Infectious Diseases, 10(1), 322.

Huang, Y., and Zhao, N. (2020). Generalized anxiety disorder, depressive symptoms and sleep quality during COVID-19 epidemic in China: a web-based crosssectional survey. medRxiv. doi: https://doi.org/10.1101/2020.02.19.20025395

Jacobson, N. C., Lekkas, D., Price, G., Heinz, M. V., Song, M., O'Malley, A. J., and Barr, P. J. (2020, April 8). Flattening the Mental Health Curve: COVID-19 Stay-atHome Orders are Associated with Alterations in Mental Health Search Behavior in the United States. https://doi.org/10.2196/19347

Ha, T., Schensul, S., Lewis, J., and Brown, S. (2020). Early assessment of knowledge, attitudes, anxiety and behavioral adaptations of Connecticut residents to COVID-19. medRxiv. doi: https://doi.org/10.1101/2020.05.18.20082073

Kannis-Dymand, L., Carter, J. D., Lane, B. R., and Innes, P. (2019). The relationship of peritraumatic distress and dissociation with beliefs about memory following natural disasters. Australian Psychologist, 54(4), 311-321.

Kılınç, G., Yıldız, E. and Harmanc, P. (2017). Toplumsal travmatik olaylar ve aile ruh sağlığı. Turkiye Klinikleri J Psychiatr Nurs, 3(2), 182-188.

Krueger, R. F., Kotov, R., Watson, D., Forbes, M. K., Eaton, N. R., Ruggero, C. J., ... ,Bagby, R. M. (2018). Progress in achieving quantitative classification of psychopathology. World Psychiatry, 17(3), 282-293.doi. org/10.1002/wps.20566 
Kumar, R., Singh, C., Saifi, A., Kumar, S., and Kumar, B. (2020). CoronaVirus, Precaution and Some Treatments. American Journal of Biomedical Research, 8(1), 15-18.

Lee, A.M., Wong, J.G., McAlonan, G.M., Cheung, V., Cheung, C., Sham, P.C., Chu, C.M., Wong, P.C., Tsang, K.W. and Chua, S. E. (2007). Stress and psychological distress among SARS survivors 1 year after the outbreak. The Canadian Journal of Psychiatry, 52(4), 233-240.

Lev, E. L., and Owen, S. V. (1996). A measure of self-care self-efficacy. Research in Nursing $\mathcal{E}$ Health, 19(5), 421-429.

Ling, G. H. T., and Ho, C. M. (2020). Effects of the coronavirus (COVID-19) pandemic on social behaviours: From a Social Dilemma Perspective. Technium Social Sciences Journal, 7(1), 312-320.

Lippi, G., Henry, B.M., Bovo, C., and Sanchis-Gomar, F. (2020). Health risks and potential remedies during prolonged lockdowns for coronavirus disease 2019 (COVID-19). Diagnosis, 1(ahead-of-print).

Liu, X., Liu, J., and Zhong, X. (2020). Psychological State of College Students During COVID-19 Epidemic. Available at SDRN 3552814.

Mak, W. W., Law, R. W., Woo, J., Cheung, F. M., and Lee, D. (2009). Social support and psychological adjustment to SARS: The mediating role of self-care selfefficacy. Psychology and Health, 24(2), 161-174.

McComas, K. A., and Trumbo, C. W. (2001). Source credibility in environmental health risk controversies: Application of Meyer's Credibility Index. Risk Analysis, 21, 467-480.

Moghanibashi-Mansourieh, A. (2020). Assessing the anxiety level of Iranian general population during COVID-19 outbreak. Asian Journal of Psychiatry, 102076.

Nishi, D., Matsuoka, Y., Yonemoto, N., Noguchi, H., Kim, Y., and Kanba, S. (2010). Peritraumatic Distress Inventory as a predictor of post-traumatic stress disorder after a severe motor vehicle accident. Psychiatry and clinical neurosciences, 64(2), 149-156.

Ozamiz-Etxebarria, N., Dosil-Santamaria, M., Picaza-Gorrochategui, M., and IdoiagaMondragon, N. (2020). Stress, anxiety, and depression levels in the initial stage of the COVID-19 outbreak in a population sample in the northern Spain. Cadernos de Saúde Pública, 36, e00054020.

Öztürk, A., (2008). Manisa Celal Bayar Üniversitesi Beden Eğitimi Ve Spor Yüksekokulu Öğretmenlik Programı ögrencilerinin durumluk ve sürekli kaygr düzeyleri ile akademik başarlar arasındaki ilişki. Yayınlanmamış Yüksek Lisans Tezi, Pamukkale Üniversitesi Sağlık Bilimleri Enstitüsü Sporda Psiko-Sosyal Alanlar Anabilim Dal, Denizli. 
Park, S.C. and, Park, Y.C. (2020). Mental health care measures in response to the 2019 novel coronavirus outbreak in Korea. Psychiatry Investig., 17, 85-6.

Perin, C., Beghi, M., Cerri, C. G., Peroni, F., Vigano, B., and Cornaggia, C. M. (2015). Experience of group conversations in rehabilitation medicine: methodological approach and pilot study. Journal of Medicine and the Person, 13(2), 96104.doi.org/10.1007/s12682-015-0208-7.

Rana, W., Mukhtar, S., and Mukhtar, S. (2020). Mental health of medical workers in Pakistan during the pandemic COVID-19 outbreak. Asian Journal of Psychiatry, 51, doi: 10.1016/j.ajp.2020.102080.

Rosendal, S., Şalcioğlu, E., Andersen, H. S., and Mortensen, E. L. (2011). Exposure characteristics and peri-trauma emotional reactions during the 2004 tsunami in Southeast Asia-what predicts posttraumatic streSd and depreSdive symptoms?. Comprehensive psychiatry, 52(6), 630-637.

Rothan, H. A., and Byrareddy, S. N. (2020). The epidemiology and pathogenesis of coronavirus disease (COVID-19) outbreak. Journal of Autoimmunity, 102433.

Roy, D., Tripathy, S., Kar, S. K., Sharma, N., Verma, S. K., and Kaushal, V. (2020). Study of knowledge, attitude, anxiety \& perceived mental healthcare need in Indian population during COVID-19 pandemic. Asian Journal of Psychiatry, 102083.

Rybojad, B., Aftyka, A., \& Milanowska, J. (2019). Peritraumatic distress among emergency medical system employees: A proposed cut-off for the Peritraumatic Distress Inventory. Annals of Agricultural and Environmental Medicine: Aaem, 26(4), 579-584.

Shanafelt, T., Ripp, J., and Trockel, M. (2020). Understanding and addressing sources of anxiety among health care professionals during the COVID-19 pandemic. Jama. 323(21), 2133-2134.

Shevlin, M., McBride, O., Murphy, J., Gibson Miller, J., Hartman, T. K., Levita, L., ... Bentall, R. (2020, April 18). Anxiety, depression, traumatic stress, and covid19 related anxiety in the UK General Population During the COVID-19 Pandemic. https://doi.org/10.31234/osf.io/hb6ng

Siegrist, M., Cvetkovich, G. T., and Gutscher, H. (2001). Shared values, social trust, and the perception of geographic cancer clusters. Risk Analysis, 21(6), 1047-1054.

Siegrist, M., Keller, C., \&and Kiers, H. A. (2005). A new look at the psychometric paradigm of perception of hazards. Risk Analysis: An International Journal, 25(1), 211-222. 
Spielberger, C.D., Gorsuch, R.L., Lushene, R., Vagg, P.R., and Jacobs, G.A. (1983). Manual for the State-Trait Anxiety Inventory. Palo Alto, CA: Consulting Psychologists Press.

Sweeny, K., and Dooley, M. D. (2017). The surprising upsides of worry. Social and Personality Psychology Compass, 11(4), e12311. https://doi.org/10.1111/spc3.12311

Teo, S. S. S., Nguyen-Van-Tam, J. S., and Booy, R. (2005). Influenza burden of illness, diagnosis, treatment, and prevention: What is the evidence in children and where are the gaps? Archives of Disease in Childhood, 90(5), 532-536.

The World Health Organization (2020a). Rolling updates on coronavirus disease (covid-19)https://www.who.int/emergencies/ diseases/novel-coronavirus2019/events-as-they-happen Retrieved 24.04.2020

The World Health Organization (2020b). Coronavirus (COVID-19) https://covid19.who.int retrieved on 24.04.2020

Wang, C., Pan, R., Wan, X., Tan, Y., Xu, L., Ho, C.S., and Ho, R.C. (2020). Immediate psychological responses and associated factors during the initial stage of the 2019 coronavirus disease (COVID-19) epidemic among the general population in China. International Journal of Environmental Research and Public Health, 17(5), 1729.

\section{Kaynakça Bilgisi / Citation Information}

Ermağan Çağlar, E. A., Hamzaoğlu, N., Özcan Sanal, Y. ve Kurtça Türk, T. (2021) Investigation of anxiety and peritraumatic distress levels in context of various variables through covid-19 outbreak: Turkey, the UK and the USA comparison. OPUS-Uluslararası Toplum Araştırmaları Dergisi, 17(Pandemi Özel Sayıs1), 3221-3244. DOI: 10.26466/opus. 830148 